\title{
Leadership Perceptions in Collaborative Marketing Groups: Cases from the Southern Philippines
}

\author{
M.O. Montiflor, J.T. Axalan, R.J.G. Lamban, R.R. Real and S.B. Concepcion \\ University of the Philippines Mindanao \\ The Philippines \\ P.J. Batt, R.B. Murray-Prior and M.F. Rola-Rubzen \\ Curtin University \\ Perth \\ Western Australia
}

Keywords: clusters, cooperative groups, vegetable marketing

\begin{abstract}
Numerous smallholder vegetable farmers in the Southern Philippines have been organized into clusters or collaborative marketing groups. The purpose of these clusters is to gain production, marketing and capacity building support, consolidate produce for higher value markets, deliver in bulk to save on transport and transaction costs, and to increase household income. One of the factors influencing the ability of the clusters to achieve these goals is leadership. Using the case study method, this study looks at the leadership traits of cluster leaders in Bukidnon, South Cotabato and Davao City. A total of 35 smallholder farmers from the three areas were interviewed using a structured questionnaire. The research showed that the clusters have trusted leaders. The members have high regard towards their leaders. Their definition of an ideal leader fits the description of their current leaders. The members also trust their leaders to represent them in transactions and meetings.
\end{abstract}

\section{INTRODUCTION}

In Mindanao, the second biggest island in the Philippines, many smallholder farmers have engaged in cluster farming to collaboratively market their vegetable products (Axalan et al., 2010; Montiflor et al., 2010; Real et al., 2010; Lamban et al., 2010; Montiflor, Batt and Murray Prior, 2009; Montiflor, 2008; Montiflor, Batt and Murray-Prior, 2008; Concepcion, Digal and Uy, 2007; Mendoza, 2006; Uy, 2005).

In the cluster, the farmers collectively plan their production and marketing activities. A study by Montiflor (2008) on three clusters in Mindanao identified the issues and challenges faced by smallholder farmer groups. These included the sustainability of financial support, the difficulty in sustaining active farmer members, encouraging farmers to cooperate once they were in the cluster, and the need for more farmer leaders.

Leadership is the process of directing and influencing (Stoner et al., 1995; Wright, 1996). Leadership is a social influence process (Lewis, et al., 1995) that involves taking actions (Massie, 1987) to produce change. Leadership is one of the most important factors of a successful cluster.

There are several different theories of leadership including trait theory, behavior theory, contingency theory and charismatic leadership (Robbins and DeCenzo, 2001). Trait theory looks at the qualities possessed by the individual. Here there is an implicit assumption that some individuals are 'natural leaders' (Lewis et al., 1995). Behavioural 
theory, on the other hand, looks at how the leader exercises his/her authority. The identifiable leadership behaviours are dictatorial, benevolent-autocratic, democratic and laissez-faire (Massie, 1987; Robbins and DeCenzo, 2001). Contingency theory, developed by Fiedler, suggests that a person's leadership style is relationship or task oriented (Robbins and Coulter, 1999). Charismatic theory suggests that there are some people who use their charisma to lead others (Wright, 1996).

This study will look into the leadership of 15 vegetable farmer clusters assisted by the Australian Centre for International Agricultural Research. This study will describe the members' perceptions of selected vegetable leaders from South Cotabato, Davao City and Bukidnon. It will look into the similarities and differences in the qualities of the farmer leaders as perceived by their members.

\section{MATERIALS AND METHODS}

The study utilized a case study methodology. According to Yin (1994, p. 13), a case study is an 'empirical inquiry that investigates a contemporary phenomenon within its real-life context'. The sample is small and the analysis is not primarily a matter of numbers (Harper and Roy, 2000). George and Bennet (2005) identified four strong advantages of case study methods: (i) its conceptual validity; (ii) its capacity to derive new hypotheses; (iii) its capacity to explore causal mechanisms; and (iv) its capacity to model and assess complex causal relationships.

This study used trip reports, case study reports, project documents, observations and informal interviews as qualitative sources of data. A structured questionnaire was used to gather information on cluster membership and leadership. Finsterbusch, Ingersoll and Llewellyn (1990) reported that while questionnaires are practical to use, researchers should always look at the local context and situation before administering. The questionnaire for the farmers was translated into a local dialect and administered in a personal face-to-face interview.

The respondents were drawn from 15 farmer clusters from South Cotabato, Davao City and Bukidnon (Table 1). Each of the clusters had an elected set of officers, including a leader, deputy leader, secretary and marketing officer. The election of other office bearers such as auditor and public information officer depended on the cluster.

\section{Background of the areas}

The South Cotabato vegetable clusters were located in the municipalities of Surallah (Barangay Duengas), Tupi (Barangay Kablon) and Lake Sebu (Barangay Ned). These areas are mostly accessible by public motorcycles. Vegetable production is an alternative cash crop while waiting for the rice or corn harvest. The populations of the Barangays were: Ned - 15,907 (National Statistical Coordination Board, 2012); Kablon 4,880; and Duengas - 829 (Philippine Islands, 2012).

The Davao City clusters were located in Barangay Marilog and Barangay Saloy. Barangay Marilog is approximately $51 \mathrm{~km}$ from Davao City centre. The barangay has a total land area of 17,833 ha with a population of 14,255 (National Statistics Office, 2007). The barangay produces vegetables such as eggplant, squash and bitter gourd. Barangay Saloy had a population of 1,699.

The two clusters in Bukidnon were drawn from the municipality of Lantapan (Barangay Songco and Kaautan), while one cluster was from Malaybalay City (Barangay Canayan). Songco had a population of 3,122, while Kaautan had 1,736. Barangay Canayan had a population of 4,621 (NSCB, 2012). 


\section{Profile of the case participants}

The study interviewed 35 farmers who were between 23-68 years old. The majority of the respondents were female (54\%). Eight of them were officers (Secretary, Marketing Officer, Auditor, Public Information Officer or Vice President) of the cluster, while the rest were members (Table 2). Around 54\% had joined their cluster in 2010, while others had joined in 2009 (20\%), 2008 (9\%) and 2007 (17\%).

\section{RESULTS AND DISCUSSIONS}

The majority of the respondents $(77 \%)$ indicated that their cluster leaders had been elected through a democratic vote, while $6 \%$ replied that only a small group of cluster members had elected the cluster leader. On the other hand, $17 \%$ believed that their cluster leader had been appointed by outsiders.

When asked about their definition of leadership, most of the respondents defined leadership as having a good management style (66\%) and to lead a group (43\%). Other definitions included being able to implement plans (14\%), to have experience in farming (3\%), to be able to improve and to help the group to prosper $(6 \%)$, to be articulate $(17 \%)$ and to serve as a good example (8\%)(Table 3 ).

When the respondents were asked to describe their ideal leader, they indicated that a leader should be honest, outspoken, experienced, responsible, active and trustworthy (Table 4). An ideal leader was also a good follower, who led by example and had a good relationship with the members, was transparent, had the ability to look at problems, communicated well and was willing to give their time.

The farmers were then asked to rate a number of constructs relating to leadership and trust on a scale of 1 to 4 where 1 was 'I disagree a lot' and 4 was 'I agree a lot'. Except for the topic on the cluster head delivering what he/she had promised and a satisfactory prior relationship, the farmers agreed with all of the statements (Table 5). In all cases, the cluster leaders were popular people within the community who were perceived to be trustworthy. They also agreed that their cluster leader was a respectable person who had a good reputation in the community, who treated them and other members of the cluster fairly and equitably. The cluster members relied on their cluster leaders to represent them and would not hesitate to follow the cluster leader's suggestions in making important selling decisions.

However, in the case of Bukidnon, only one respondent had any prior relationship with their cluster leader. For the other farmers, it was their first time to work with the cluster leader. Cluster farmers in South Cotabato rated their cluster leader poorly on their ability to deliver what he/she had promised. This was due to their perception that some of their money had been misappropriated by the cluster leader because he did not remit the marketing fee to the treasurer. The group had already replaced this cluster leader.

When farmers were asked to describe their current leader, it was immediately apparent that there was a great deal of similarity between the farmers' ideal leader and their current leader (Table 6). They described their current leaders as active, seasoned leaders, who currently held or had previously held a key position in the community, were knowledgeable in vegetable farming and marketing, respectful, patient, God-fearing and trustworthy. The respondents also described their current leaders as good managers who personally informed members about meetings, listened to their problems, did not scold them, and could clearly explain activities and policies to members. The cluster leaders had a good attitude, were willing to give their time and were keen to unite all members of the cluster. 


\section{Profile of the cluster leaders}

The cluster leaders had much in common with each other, but there were also many differences (Table 7). Ten of the cluster leaders were male while five were female. Their ages ranged from early 30's to late 50's. The highest level of education attained ranged from finishing some elementary school to having a vocational degree. Eight of them were Roman Catholics. Except for one cluster leader from Davao City, they were former/current members and/or leaders of other groups. Most had been farming for an average of 27 years. Aside from one widower, all of the respondents were married. They were also trusted and respected in the community and had a good reputation.

\section{Importance of leadership in the clusters}

Leadership was identified as one of the most important factors in the success of a cluster. In Davao City, for example, the cluster leaders encouraged their members to continue planting and to collectively sell their produce to the market. This resulted in continuing deliveries to both the traditional market (Montiflor et al., 2011) and the focal institutional market (Lamban et al., 2011). On the other hand, in South Cotabato, the dwindling number of farmers in the cluster was a direct result of poor leadership and the lack of commitment (Axalan et al., 2011).

\section{CONCLUSION}

While there may be many differences in the leadership styles across the clusters, it was apparent that some typologies (or general characteristics) can be derived. The leadership behaviour of the cluster leader was mostly democratic. Personal and process based trust was very important in a collaborative relationship (Kotilla and Ronni, 2008). Time, resources and management skill had been invested over an extended period to develop this trust.

The research revealed that the successful clusters generally had trusted leaders. Cluster farmers need trusted leaders to ensure an attainable and sustainable work plan. The members generally had a high regard towards their leaders. Their definition of an ideal leader fitted the description of their current leaders. The members also trusted their leaders to represent them in transactions and meetings.

\section{ACKNOWLEDGMENT}

Australian Centre for International Agricultural Research (ACIAR) HORT 2007/066/04 Philippine Council for Agriculture, Aquatic and Natural Resources Research and Development.

\section{Literature Cited}

Axalan, J.T., Israel, F.T., Concepcion, S.B. 2011. Factors Affecting the Contraction of Cluster Marketing: The Case of Vegetable Cluster Marketing in Southern Mindanao. Proceedings $3^{\text {rd }}$ Agribusiness Economics Conference. Enhancing the performance of the Agribusiness Industry: Linking Research Findings to Users, Apo View Hotel, Davao City, July.

Axalan, J.T., Israel, F.T., Concepcion, S.B. Batt, P.J., Murray-Prior, R.B. and Loma, L. 2010. Socio-economic Impact of Cluster Marketing: The Case of Ned Landcare Association Sweet Pepper Cluster. Acta Horticulturae 895: 2010. 
Concepcion, S.B., Digal, L.N. and Uy, J.C. 2007. The case of NorminVeggies of Northern Mindanao, Philippines. In Batt, P.J. and Cadilhon, J-J. (ed) Proceedings of the International Symposium on Fresh Produce Supply Chain Management. RAP Publication 2007/21: 229-239.

Finsterbusch, K., Ingersoll, J. and Llewellyn, L. 1990. Methods for Social Analysis in Developing Countries. Westview Press, Colorado.

George, A.L. and Bennett, A. 2005. Case Studies and Theory Development in the Social Sciences. The MIT Press, Cambridge, Mass.

Harper, M. and Roy, A.K. 2000. Cooperative Success. ITDG Publishing, Lon.

Kottila, M.R. and Ronni, P. 2008. Collaboration and trust in two organic food chains. British Food Journal, 110(4/5): 376-394.

Lamban, R.J.G., Montiflor, M.O., Concepcion, S.B., Bacus, R.H., Ramirez, L.A., Batt, P.J. and Murray-Prior. R.B. 2011. Pamuhatan Farmers Association Collaborative Marketing Experience. Proceedings $3^{\text {rd }}$ Agribusiness Economics Conference. Enhancing the performance of the Agribusiness Industry: Linking Research Findings to Users, Apo View Hotel, Davao City, July.

Lamban, R.J.G., Montiflor, M.O., Dela Cerna, A.K.R., Bacus, R.G., Ramirez, L.A., Concepcion, S.B., Batt, P.J. and Murray-Prior. R.B. 2010. Factors affecting farmers' adoption of natural farming technologies in New Albay, Maragusan, Compostela Valley, Philippines. Acta Horticulturae 895: 153-158.

Lewis, P.S., Goodman, S.H. and Fandt, P.M. 1995. Management: Challenges in the 21st Century (Second ed.). Cincinnati, Ohio: International Thompson Publishing.

Massie, J.L. 1987. Fundamentals of Management. $4^{\text {th }}$ Ed. Prentice-Hall, Inc. New Jersey.

Mendoza, L. 2006. The Experiences of CRS in Clustering. Proceedings $3^{\text {rd }}$ Mindanao Vegetable Congress, Cagayan de Oro City, Philippines.

Montiflor, M.O., Lamban, R.J.G., Montiflor, M.O., Bacus, R.H., Batt, P.J. and MurrayPrior. R.B. 2011. Factors Affecting Collaborative Marketing Group Expansion: Case of Saloy, Calinan District, Philippines. Proceedings $3^{\text {rd }}$ Agribusiness Economics Conference. Enhancing the performance of the Agribusiness Industry: Linking Research Findings to Users, Apo View Hotel, Davao City, July.

Montiflor, M.O., Dela Cerna, A.K.R., Lamban, R.J.G., Bacus, R.G., Concepcion, S.B., Batt, P.J. and Murray-Prior. R.B. 2010. Social connections and smallholder vegetable farmers' collaborative marketing strategy: the case of small farmers association of Quirogpang in Davao City, Philippines. Acta Horticulturae 895: 177-184.

Montiflor, M.O., Batt, P.J. and Murray-Prior, R. 2009. Socio-economic Impact of Cluster Farming for Smallholder Farmers in Southern Philippines. Acta Horticulturae 809: 193-200.

Montiflor, M.O., Batt, P.J. and Murray-Prior, R. 2008. Cluster Farms in Mindanao: Are Smallholder Farmers' Expectations Being Fulfilled? BANWA 2(2): 39-54.

Montiflor, M.O. 2008. Cluster Farming as a Vegetable Marketing Strategy: The Case of Smallholder Farmers in Southern and Northern Mindanao. Acta Horticulturae 794: 229-238.

National Statistical Coordination Board. 2012. Municipality/City: LAKE SEBU.

National Statistical Coordination Board. 2012. Municipality/City: LANTAPAN.

National Statistical Coordination Board. 2012. Municipality/City: MALAYBALAY CITY. 
National Statistics Office. 2007. Census of Population (Publication. Retrieved January

21, 2010, from National Statistics Office:

http://www.census.gov.ph/data/sectordata/2007/region\%2011.pdf

Philippine Islands. 2012. Tupi Barangays.

Real, R.R., Hualda, L.A.T., Apara, D.I., Concepcion, S.B., Batt, P.J. and Murray-Prior,

R.B. 2010. Microfinance as the key factor affecting farmers' investment decisionmaking: cluster experiences in Impasugong, Bukidnon, Philippines. Acta Horticulturae 895: 239-244.

Robbins, S.P. and Coulter, M. 1999. Management. $6^{\text {th }}$ Ed. Prentice-Hall Inc. New Jersey.

Robbins, S.P. and DeCenzo, D.A. 2001. Fundamentals of Management. $3^{\text {rd }}$ Ed. PrenticeHall Inc. New Jersey.

Stoner, J.A.F., Freeman, E.E. and Gilbert, D.R. 1995. Management. $6^{\text {th }}$ Ed. New Jersey, USA: Prentice-Hall.

Uy, J.C. 2005. Cluster Farming: The NorMin Veggies Experience. Proceedings $2^{\text {nd }}$

Mindanao Vegetable Congress, Davao City, Philippines. August.

Wright, P.M. and Noe, R.A. 1996. Management of Organizations. USA: Richard D. Irwin.

Yin, R.B. 1994. Case Study Research: Design and Methods. $2^{\text {nd }}$ Ed. Sage Publications.

Table 1: Members of Clusters

\begin{tabular}{|l|c|c|c|}
\hline \multicolumn{1}{|c|}{ Area } & $\begin{array}{c}\text { Total number of } \\
\text { clusters }\end{array}$ & $\begin{array}{c}\text { Total number } \\
\text { of members }\end{array}$ & Respondents \\
\hline Bukidnon & 3 & 39 & 6 \\
\hline Davao City & 7 & 104 & 19 \\
\hline South Cotabato & 5 & 67 & 11 \\
\hline TOTAL & 15 & 210 & 35 \\
\hline
\end{tabular}

Table 2: Position in the cluster

\begin{tabular}{|l|c|c|}
\hline \multicolumn{1}{|c|}{ Position } & Frequency & Percent \\
\hline Member & 27 & 77.1 \\
\hline Secretary & 2 & 5.7 \\
\hline Auditor & 1 & 2.9 \\
\hline PIO & 1 & 2.9 \\
\hline Marketing Officer & 3 & 8.6 \\
\hline Vice President/Assistant Leader & 1 & 2.9 \\
\hline Total & 35 & 100.0 \\
\hline
\end{tabular}


Table 3: Definition of leadership

\begin{tabular}{|l|c|}
\hline Definition of leadership & \% (multiple answers) \\
\hline Good management & 66 \\
\hline Leads/guides a group & 43 \\
\hline Articulate & 17 \\
\hline Trustworthy & 14 \\
\hline Able to implement plans & 14 \\
\hline Good example & 8 \\
\hline Active & 6 \\
\hline Able to improve and help group to prosper & 6 \\
\hline Hard to be a leader & 6 \\
\hline Experience in farming & 3 \\
\hline Knowledgeable & 3 \\
\hline Chosen & 3 \\
\hline
\end{tabular}

Table 4: Ideal leaders

\begin{tabular}{|c|c|}
\hline Trait & Behaviour \\
\hline $\begin{array}{ll}\text { - } & \text { Honest } \\
\text { - } & \text { Trustworthy } \\
\text { - } & \text { Outspoken } \\
\text { - } & \text { Experienced } \\
\text { - } & \text { Responsible } \\
\text { - } & \text { Leadership potential } \\
\text { - } & \text { Active } \\
\text { - God-fearing }\end{array}$ & $\begin{array}{l}\text { - Can manage members well } \\
\text { - Communicates well } \\
\text { - Able to look at other people's problems } \\
\text { - Good follower } \\
\text { - Good relationship with members } \\
\text { - Transparent } \\
\text { - First to take action/ leadership by example } \\
\text { - Good planner } \\
\text { - Gives time }\end{array}$ \\
\hline
\end{tabular}

Table 5: Leadership perceptions

\begin{tabular}{|l|c|c|c|}
\hline Constructs & $\begin{array}{c}\text { South } \\
\text { Cotabato }\end{array}$ & Bukidnon & Davao City \\
\hline The cluster leader is trustworthy & 3.6 & 3.5 & 3.9 \\
\hline $\begin{array}{l}\text { My previous relationships with my cluster leader } \\
\text { are satisfactory }\end{array}$ & 3.7 & & 3.9 \\
\hline $\begin{array}{l}\text { My cluster leader can deliver what he/she } \\
\text { promised. }\end{array}$ & 2.4 & 3.7 & 3.6 \\
\hline My cluster leader is a respectable person. & 3.7 & 3.8 & 3.8 \\
\hline I can rely on my cluster leader & 3.3 & 3.8 & 3.7 \\
\hline $\begin{array}{l}\text { I do not hesitate to make important selling } \\
\text { decisions based on my cluster leader's } \\
\text { suggestion }\end{array}$ & 3.6 & 3.3 & 3.7 \\
\hline $\begin{array}{l}\text { My cluster leader is a popular person in the } \\
\text { community }\end{array}$ & 4.0 & 4.0 & 3.9 \\
\hline My cluster leader acts on my behalf & 3.8 & 3.8 & 3.6 \\
\hline $\begin{array}{l}\text { My cluster leader has a good reputation in the } \\
\text { community }\end{array}$ & 3.5 & 3.8 & 3.8 \\
\hline The cluster leader treats all members fairly & 3.6 & 3.8 & 3.9 \\
\hline
\end{tabular}


Table 6: Description of the cluster leaders

\begin{tabular}{|l|l|}
\hline \multicolumn{1}{|c|}{ Trait } & \multicolumn{1}{c|}{ Behaviour } \\
\hline $\begin{array}{l}\text { Seasoned leader; holds or held key leadership } \\
\text { positions in the community } \\
\text { - Knowledgeable in farming and marketing } \\
\text { vegetables }\end{array}$ & $\begin{array}{l}\text { - Good manager } \\
\text { - Communicates well/ articulate }\end{array}$ \\
$\begin{array}{l}\text { Respectful } \\
\text { - Patient }\end{array}$ & $\begin{array}{l}\text { - Gives time } \\
\text { - Godisiting member's house }\end{array}$ \\
- Trustworthy & - Good example; first to implement tasks \\
- Possesses good attitude & - Does not scold members \\
& - No problems \\
\hline
\end{tabular}

Table 7: Similarities and differences of cluster leaders

\begin{tabular}{|l|l|}
\hline \multicolumn{1}{|c|}{ Similarities } & \multicolumn{1}{c|}{ Differences } \\
\hline Members of other groups, such as church, & Gender \\
cooperative, associations, local government, & Age \\
women's group & Religion \\
Has a good reputation in the community & Educational attainment \\
Trusted & \\
Respected & \\
\hline
\end{tabular}

